Artigo recebido em

20/09/2014

Aprovado em

$27 / 10 / 2014$

GABRIELA DA

SILVA ZAGO

UFPel-gabrielaz@gmail.

com

Doutoranda em

Comunicação e

Informação na

Universidade Federal do Rio Grande do Sul UFRGS. Professora dos cursos de Design Gráfico

e Design Digital da Universidade Federal de Pelotas - UFPel.

\section{Enquanto você lia este título, a Alemanha fez mais um gol: a Copa da zoeira nos sites de rede social}

\author{
Gabriela da Silva Zago
}

\section{Resumo}

O trabalho tem o objetivo de discutir o papel de piadas e remixes em torno da Copa do Mundo de 2014 diante de um cenário de jornalismo em rede. Durante a realização do evento esportivo, os espectadores utilizaram computadores e dispositivos móveis como segunda tela, o que possibilitou que piadas fossem criadas e postas em circulação praticamente em tempo real nos sites de rede social. Três desses casos são analisados no artigo, buscando demonstrar a inter-relação entre remix, humor e jornalismo.

Palavras-chave

Jornalismo em rede, Remix, Sites de rede social

\begin{abstract}
In this paper, we aim to discuss the role of jokes and remixes around FIFA's World Cup 2014 in face of a network journalism scenario. During the sporting event, viewers used computers and mobile devices as a second screen, which made possible the creation and circulation of jokes almost in real time in social network sites. In this article, we analyze three of these cases, seeking demonstrate the interrelationship among remix, humor and journalism.
\end{abstract}

Keywords

Network journalism; Remix; Social network sites
Estudos em Jornalismo e Mídia

Vol. 11 No 2

Julho a Dezembro de 2014

ISSNe 1984-6924 
1- "Brasil e Alemanha éo jogo mais tuitado da história", Zero Hora, 09 jul. 2014. Disponivel em <http://zh.clicrbs com.br/rs/esportes/copa-2014/ noticia/2014/07/brasil-e-alemanha-e-o-jogo-mais-tuitado-da-historia-4547055.html >. Acesso em: 11 jul. 2014.

2- https://twitter.com

TwitterData/statu-

ses/486708145775841281

3- "7 a 1 da Alemanha é

maior goleada da história

centenária da seleção", Folha de S.Paulo, 08 jul. 2014.

Disponivel em: <http://wwwl. folha.uol.com.br/esporte

folhanacopa/2014/07/1483037 -antes-da-alemanha-brasil-so-havia-perdido-por-6-gols-de-diferenca-em-1920.shtml $>$. Acesso em: 19 set. 2014.

4- http://odia.ig.com.br/esporte/copa-do-mundo/2014-07-14/ copa-da-zoeira-as-principais-brincadeiras-no-mundial-do-brasil.html

5- http://zh.clicrbs.com.

br/rs/esportes/copa-2014/ noticia/2014/07/copa-da-zoeira-10-memes-que-marcaram-o-mundial-4550521.html

6 - http://copadomundo.

uol.com.br/noticias

redacao/2014/06/27/a-copa-

-das-copas-tambem-e-a-copa

-da-zoeira.htm

7- http://info.abril.com.br/

noticias/internet/fotonoticias/ copa-da-zoeira-os-melhores-memes-da-copa-do-mundo-2014.shtml

8-http://esportes.r7.com futebol/copa-do-mundo-2014 fotos/reunimos-mais-de-300-memes-engracados-da-copa-relembre-10082014\#!/foto/1 9 - http://wwwl.folha.uol. com.br/tec/2014/06/1478398 - hashtag-esta-e-a-copa-da-zoeira-e-ja-temos-a-prova-definitiva-disso.shtml

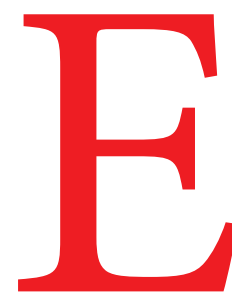

m 2014, o Brasil foi sede de um dos maiores eventos esportivos do planeta, a Copa do Mundo de 2014 organizada pela FIFA. Durante o evento, internautas de todo o país e do mundo recorreram aos sites de rede social para tecer comentários e considerações sobre as partidas e sobre o evento. $\mathrm{O}$ uso das redes foi tão intenso que a partida entre Brasil e Alemanha pelas semifinais da Copa do Mundo, em 04 de julho de 2014, tornou-se o evento esportivo mais tuitado da história ${ }^{1}$, com 35,6 milhões de tweets ${ }^{2}$.

Mensagens de diferentes naturezas foram postadas pelos usuários. Dentro desse contexto, destacam-se as atualizações de humor, com piadas e remixes associados ao evento esportivo. A própria partida entre Brasil e Alemanha foi um dos acontecimentos relacionados à Copa que suscitou um grande número de piadas, devido ao inusitado da situação - a derrota do Brasil por 7 a 1, a maior derrota da seleção brasileira em Copas ${ }^{3}$.

O humor nas postagens durante a Copa esteve tão presente que inúmeros veículos jornalísticos - como O Dia ${ }^{4}$, Zero Hora ${ }^{5}$, $\mathrm{UOL}^{6}$, Info ${ }^{7}, \mathrm{R}^{8}$ e Folha de S.Paulo ${ }^{9}$ - passaram a se referir a ela como "Copa da Zoeira”. É a partir desse entrelaçamento entre o humor produzido pelos interagentes e o cenário de jornalismo em rede que o presente artigo se situa.

O trabalho tem o objetivo de discutir o papel de piadas e remixes em torno da Copa do Mundo de 2014 diante de um cenário de jornalismo em rede. Durante a realização do evento esportivo, os espectadores utilizaram computadores e dispositivos móveis como segunda tela, o que possibilitou que piadas fossem criadas e postas em circulação praticamente em tempo real nos sites de rede social. Essas piadas foram então compiladas por veículos jornalísticos diversos, demonstrando uma relação de complementaridade entre sites de rede social e jornalismo.

O artigo está estruturado da seguinte forma: em um primeiro momento, discorre-se sobre o jornalismo em rede e os sites de rede social. Na sequência, aborda-se o remix enquanto um elemento típico da cibercultura. Após, três casos ilustrativos são estudados para mostrar a complementaridade entre as piadas que surgiram na rede e o jornalismo. Por fim, são traçadas as considerações finais.

\section{Jornalismo em rede e sites de rede social}

Se no passado era possível delimitar claramente as fronteiras entre o jornalismo e a esfera social, cada vez mais os limites entre ambos passam a se tornar difusos. Por influência dos sites de rede social, o próprio jornalismo se reconfigura, buscando se aproximar da linguagem do público e incorporando a participação dos usuários.

$\mathrm{O}$ jornalismo em rede se refere a uma perspectiva que busca compreender o jornalismo como uma rede em que diversos atores e veículos se complementam na produção e circulação de conteúdos (Heinrich, 2011; Russell, 2011). Nesse contexto, os veículos jornalísticos, ao lado de blogs, interagentes, e outros meios alternativos, seriam nós numa complexa e densa rede de informações. "Com um crescente número de distribuidores de notícias entrando na cadeia de produção jornalística, a troca de informações está se tornando uma conversação interativa" (Heinrich, 2011, p. 
I ${ }^{10}$. Novos atores entram em cena, tanto na produção quanto na circulação de notícias. Nessa perspectiva, não apenas veículos jornalísticas e jornalistas são considerados nós no processo jornalístico. Outros possíveis nós passam a ser considerados, como a testemunha que relata um fato em um blog, ou o usuário que compartilha uma foto no Facebook.

Os sites de rede social se inserem nesse processo como espaços em que essas práticas diferenciadas de jornalismo podem se manifestar - como suporte tanto para a produção quanto para a circulação de notícias. Para Ellison \& boyd (2013), um site de rede social pode ser definido como espaços da web que possibilitam a seus participantes: a) criar um perfil de identificação única, b) articular publicamente conexões e c) consumir, produzir e interagir com fluxos de conteúdos criados pelos usuários do site. Cada participante, através de seu perfil, está conectado a grupos de usuários diferentes, o que gera fluxos de conteúdos diferentes para cada participante. $\mathrm{O}$ fato de as redes serem diferentes faz com que seja possível e relevante não só criar como também compartilhar conteúdos nesses espaços.

Sites de rede social podem ser relacionados ao jornalismo de diferentes maneiras. Recuero (2009) aponta três formas de relação entre redes sociais e jornalismo: as redes sociais podem atuar como produtoras de informação, como filtros de informação ou ainda como espaços de reverberação dessas informações. A atuação como fonte se dá quando uma discussão surgida na rede recebe atenção da mídia. A atuação como filtro está relacionada à possibilidade de os usuários compartilharem e reproduzirem conteúdos originalmente postados pelos veículos jornalísticos. A reverberação, por sua vez, está associada a uma intensa circulação de informações sobre determinados assuntos. A própria reverberação de um determinado acontecimento pode se transformar em uma nova pauta para o jornalismo, realçando o papel das redes sociais enquanto fontes para o jornalismo.

As características da internet permitem que "as redes não apenas difundam, mas igualmente discutam essas informações" (Recuero, 2009, p. 49). As redes sociais exerceriam, assim, caráter complementar ao veículos jornalísticos, "não tendo o mesmo comprometimento que estes para com a credibilidade da informação, mas auxiliando a mobilizar pessoas, a construir discussões, e até mesmo, a apontar diversidades de pontos de vista a respeito de um mesmo assunto" (Recuero, 2009, p. 50).

Esse entrelaçamento entre sites de rede social e jornalismo contribui para a constituição de um cenário de jornalismo em rede, em que diversos atores contribuem, de formas variadas, para a produção e circulação de notícias.

Relacionado a esse cenário, há uma crescente utilização de sites de rede social - em especial, o Twitter - como "segunda tela" (Finger \& Souza, 2012). Com isso, cria-se um canal paralelo de conversação em torno de determinados programas televisivos. Esse conteúdo visto originalmente na televisão e tuitado em tempo real pode ainda suscitar uma conversa com um amigo em um mensageiro instantâneo, gerar posts, comentários, curtidas e compartilhamentos no Facebook, influenciar a produção de reportagens no jornal impresso e até mesmo levar à produção de críticas na imprensa especializada, as quais, por sua vez, poderão novamente ser comentadas, curtidas e compartilhadas nos sites de rede
10- Tradução de: "With a growing number of news distributors entering the news production chain, information Exchange is turning into an interactive conversation" (Heinrich, 2011, 
social. Essas múltiplas relações entre conteúdos, produtores e circuladores de notícia demonstram as complexas propriedades combinatórias de um jornalismo em rede.

Durante eventos esportivos como partidas da Copa, por exemplo, é possível utilizar um site de rede social para fazer postagens durante o transmissão das partidas. Especificamente na Copa de 2014, foi possível observar inúmeras postagens, com cobertura em tempo real, críticas ao evento esportivo, e também piadas e remixes.

\section{Cibercultura remix e apropriações}

A criação e circulação de conteúdos em sites de rede social se inserem em um contexto de cibercultura remix. Para Lemos (2005, p. 1), o princípio que rege a cibercultura é a remixagem, um "conjunto de práticas sociais e comunicacionais de combinações, colagens, cut-up de informação a partir das tecnologias digitais". A combinação das tecnologias com esses novos processos comunicacionais daria lugar a uma nova configuração cultural que o autor chama de cibercultura remix: "Por remix compreendemos as possibilidades de apropriação, desvios e criação livre a

11- Tradução de "Appropriation: the process through which mobile phone users go beyond mere adoption to make the technology their own and to embed it within their social, economic, and political practices". partir de outros formatos, modalidades ou tecnologias, potencializados pelas características das ferramentas digitais e pela dinâmica da sociedade contemporânea" (Lemos, 2005, p. 2).

A ideia de remix não seria exclusiva do ambiente digital. Inicialmente, o termo remix era usado para descrever a combinação de duas ou mais músicas. Posteriormente, passou a ser aplicado nos mais diversos setores, como no caso da arte (Bastos, 2007) e do audiovisual (Soares, 2005). O ambiente digital abre possibili- dades de recriações a partir de conteúdos disponibilizados em rede. Essas recriações partem de uma apropriação do conteúdo, que é reconfigurado e remixado para fazer servir a um novo propósito, como no caso de combinar duas ou mais imagens para gerar um efeito de humor.

As imagens remixadas podem se transformar em memes, sendo repetidas à exaustão. Para Dawkins (2007), memes são ideias que se repetem por imitação. Para o autor, o conceito de meme estaria associado ao de gene. Assim como um gene, o meme se replica, mas ao mesmo tempo se transforma à medida em que circula. Os sites de rede social fornecem três elementos essenciais para um meme enquanto replicador: a longevidade, a fecundidade e a fidelidade das cópias. Assim, os sites de rede social permitem que uma ideia se propague no tempo (longevidade), inúmeras vezes (fecundidade) e em cópias iguais ou similares ao original (fidelidade das cópias), tornando-se um terreno fértil para a propagação de memes.

Tanto a criação de remixes quanto a incorporação desses aos produtos jornalísticos decorrem de práticas de apropriação. Ao estudar telefones móveis, Bar, Pisani \& Weber (2007, p.1) definem apropriação como "o processo através do qual usuários de celulares vão além da mera adoção para tornar a tecnologia própria e incorporá-la em suas práticas sociais, econômicas e políticas"11. Ainda que a apropriação seja muitas vezes pensada "de baixo para cima”, ou seja, como um processo através do qual o público consumidor produz modificações em um artefato criado por uma indústria criadora, esse processo também pode ocorrer "de cima para baixo", na medida em que pode envolver a criação de novos artefatos pela mídia tradicional a 
partir das práticas do público.

No contexto do jornalismo, reter a atenção da audiência pode ser um bem mais valioso do que o valor pago para ter acesso a um determinado conteúdo (Salaverría \& Negredo, 2008). Nesse sentido, estratégias diversas podem ser empregadas para conseguir captar essa atenção, como no caso de se recorrer ao humor ou a linguagens e a práticas típicas do público. Veículos jornalísticos, assim, passam a noticiar aquilo que reverbera nas redes, como uma forma de atrair ainda mais visitas para seus espaços noticiosos (Hong, 2012).

A seguir, três casos envolvendo apropriação de imagens e o entrelaçamento entre humor, sites de rede social e jornalismo são apresentados e discutidos.

\section{A Copa da zoeira}

As considerações a seguir partem da análise de três casos ilustrativos sobre a Copa da zoeira: versões modificadas de hinos nacionais, piadas com jogadores da Holanda e diálogos fictícios entre Dilma e Angela Merkel. Ainda que os três casos tenham surgido na rede, eles se inserem em um contexto de jornalismo em rede na medida em que serviram de pauta para notícias em variados veículos, o que contribuiu para retroalimentar a repercussão nas redes desses casos.

Os três casos foram escolhidos por representarem formas diferentes de se apropriar de imagens: no primeiro caso, há uma manipulação da imagem. No segundo caso, o processo é de justaposição da imagem a outros cenários. No terceiro, a imagem permanece inalterada, porém é acrescida de legendas e comentários de humor. Os casos também são representativos de algumas das temáticas que permearam as imagens compartilhadas no Twitter du- rante a Copa. Dentre outras categorias de imagens, Haacke et al (2014) identificam política, jogadores memes e hinos como algumas das temáticas mais recorrentes dentre as imagens mais compartilhadas no Twitter durante a Copa de 2014.

\section{Hinos fictícios}

O primeiro caso abordado são as imagens de hinos fictícios. Antes de cada partida da Copa, o hino nacional de cada país era executado, e a respectiva letra era exibida traduzida na tela da televisão. Em 14 de junho, uma brincadeira substituiu um trecho da letra do hino do Japão pela música de abertura de Pokémon. A partir daí, outras substituições foram feitas, incluindo trocar o hino brasileiro por trechos de "Beijinho no Ombro" e o hino da Argentina por trechos de "Macarena" (Figura 1).

Os remixes eram criados a partir de ce-

Figura 1. Hino nacional da Argentina substituído por trecho da letra de Macarena.

Fonte: http://www. correio24horas.com.br/ detalhe/noticia/inspirados-na-copa-internautas-criam-parodias-de-hinos-nacionais/?cHash=$5613414095 f 65 f e 2063 d 6 b$ $c 7 d 7 c 7726 d$

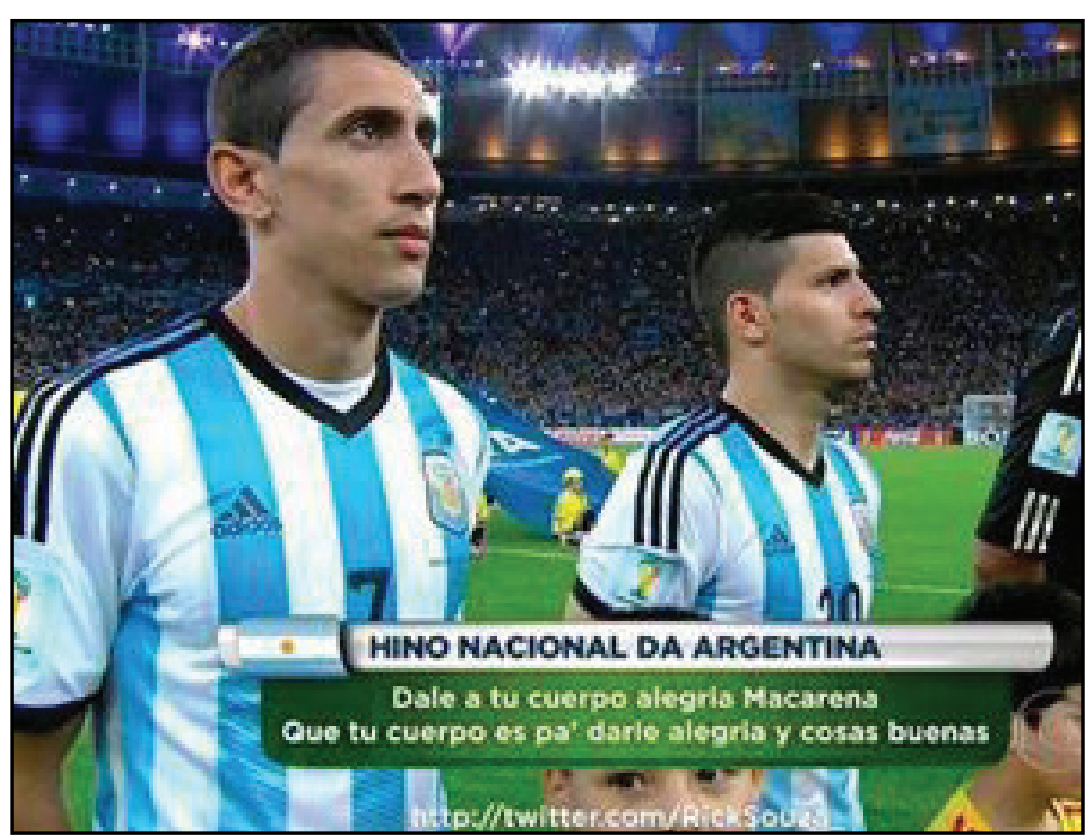

nas estáticas da tela e envolviam a sobreposição de trechos de outras músicas no local reservado para a letra do hino. Para gerar efeito de humor, as letras normalmente estavam associadas a elementos da cultura pop dos países das equipes retratadas.

$\mathrm{O}$ assunto recebeu destaque da mídia no dia 17 de junho de 2014. O jornal $O$ 
12- "“Copa da Zoeira': Hinos fictícios dos países do Mundial se destacam na Web", O Dia, 17 jun. 2014. Disponivel em. $<$ http://odia.ig.com. br/esporte/copa-do-mundo/2014-06-17/ copa-da-zoeira-hinos-ficticios-das-selecoes-do-mundial-fazem-sucesso-na-internet. html>. Acesso em: 18 set. 2014.

13- "'Hinos da zoeira” dos países da Copa do Mundo circulam nas redes sociais. Globo Esporte, 17 jun. 2014. Disponivel em: $<$ http://globoesporte. globo.com/platb/meiodecampo/2014/06/17/ hinos-da-zoeira-dos-paises-da-copa-do-mundo-circulam-nas-redes-sociais/>. Acesso em: 18 set. 2014.

14- "A Copa da Zoeira: as melhores versões dos hinos que estão rolando no Twitter", IG, 17 jun. 2014. Disponível em: <http://jovem.ig.com.br/cultura/ internet/2014-06-17/a-copa-da-zoeira-as-melhores-versoes-dos-hinos-que-estao-rolando-no-twitter. html>. Acesso em: 18 set. 2014.

15 - "Veja os memes da vitória da Holanda sobre a Espanha", Info, 13 jun. 2014. Disponivel em: <http://info. abril.com.br/noticias/ internet/fotonoticias/ veja-os-memes-da-vitoria-da-holanda-sobre-a-espanha. shtml>. Acesso em: 18 set. 2014.

16- "Com "holandês voador", Espanha é ridicularizada na web", Terra, 13 jun. 2014. Disponivel em: <http:// esportes.terra.com.br/ espanha/com-holandes-voador-espanha-e-ridicularizada-na-
$D_{i a^{12}}$ abordou o sucesso na web dos hinos fictícios das seleções do mundial. $\mathrm{O}$ site do Globo Esporte ${ }^{13}$ se referiu aos remixes como "hinos da zoeira". O canal IG Jovem $^{14}$ destacou uma galeria de imagens com "as melhores versões dos hinos que estão rolando no Twitter".

Nesse caso dos hinos fictícios, apropriações dos usuários voltadas para o humor acabam se repetindo à exaustão, replicando-se na forma de um meme. Essa reverberação do acontecimento nos sites de rede social foi tão intensa que veículos jornalísticos a noticiaram. O remix, dessa forma, se transforma em um nó do jornalismo em rede, contribuindo para diminuir as fronteiras entre jornalismo e esfera social.

Esse caso, ainda, demonstra claramente a atuação do Twitter como segunda tela - tanto como espaço para reverberação utilizado em paralelo às partidas, como também diante do fato de se tratar especificamente de uma paródia a partir de imagens captadas da tela da televisão.

\section{Jogadores da Holanda}

A atuação dos jogadores da Holanda suscitou a criação de inúmeros remixes a partir da justaposição das imagens dos jogadores a outros contextos. Alguns desses remixes viraram memes. Os primeiros memes surgiram por ocasião da vitória da Holanda sobre a Espanha por 5 a 1 em 13 de junho de 2014. Mais adiante na competição, novos memes surgiram por ocasião da vitória da Holanda sobre o Brasil por 3 a 0 na disputa pelo terceiro lugar, em 12 de julho de 2014.

Ainda que nas duas situações tenha havido goleada, o caso da Espanha é particularmente interessante porque as duas equipes haviam se enfrentado na final da Copa de 2010 - que consagrou como campeã a seleção da Espanha. Assim, o inusitado da situação foi a Holanda derrotar de goleada a atual campeã do mundial.

No primeiro caso, o jogador que mais aparece nos memes é Van Persie. A Holanda empatou com a Espanha com um gol de peixinho do jogador Van Persie. A imagem do jogador foi recortada e justaposta ao cenário do jogo Flappy Bird, em que um passarinho comandado pelo usuário deve desviar de um cenário de canos (Figura 2).

Figura 2. Remix criado com o jogador Van Persie

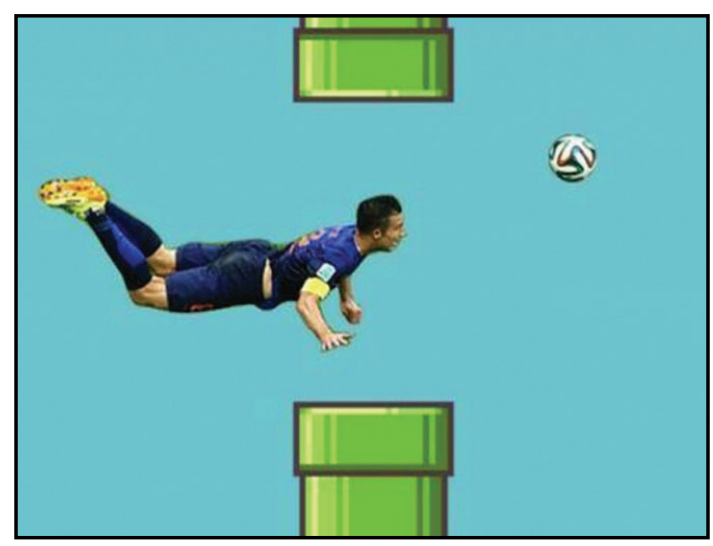

desviando de canos no cenário do jogo Flappy Bird. Fonte: http://info.abril.com.br/noticias/internet/ fotonoticias/veja-os-memes-da-vitoria-da-holanda-sobre-a-espanha.shtml

O site da revista $\operatorname{Info} \mathrm{f}^{15}$ criou uma galeria para destacar alguns dos memes da vitória da Holanda sobre a Espanha. Já a manchete do portal Terra ${ }^{16}$ destaca que a Espanha teria sido "ridicularizada na web" com as cenas do "holandês voador".

Já no segundo caso, na partida entre Brasil e Holanda, a principal vítima das montagens foi o goleiro da Holanda, Jasper Cilessen. Inúmeros remixes surgiram a partir de uma cena em que o jogador aparece como se estivesse sentado junto à trave. Uma dessas representações pode ser vista na Figura 3. 
Figura 3. Imagem do goleiro da Holanda ajustando

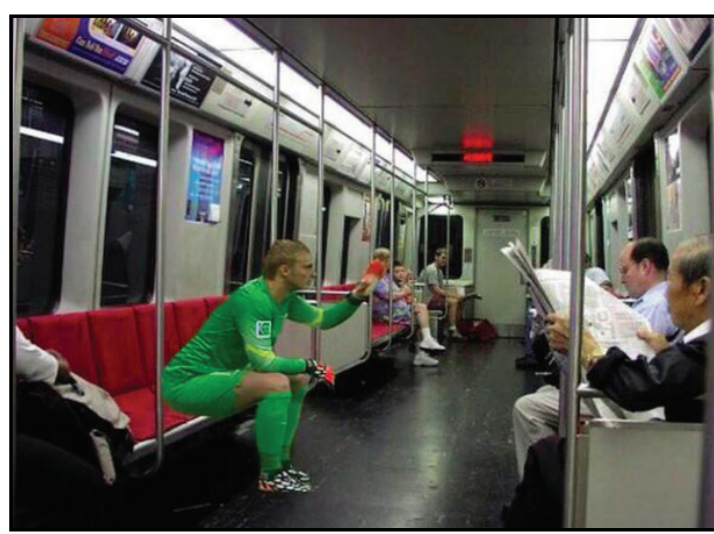

a trave justaposta a um cenário de metrô. Fonte: http://esportes.r7.com/futebol/copa-do-mundo-2014/fotos/goleiro-da-holanda-senta-durante-jogo-contra-o-brasil-e-vira-alvo-de-memes-na-internet-13072014\#!/foto/10

O portal da Empresa Brasileira de Comunicação ${ }^{17}$ destaca os memes que "bombaram" durante a partida. Já o portal R7 $7^{18}$ criou uma galeria específica para reunir apenas as montagens com o goleiro da Holanda.

Assim como no exemplo anterior, esses casos envolvendo jogadores da Holanda também reforçam a integração das redes com o jornalismo, e o papel de segunda tela da televisão com o Twitter. Se as goleadas por si sós já eram suficientes para serem noticiadas pelos veículos, a notícia esperada também foi acompanhada de situações inusitadas a partir do que aconteceu durante a partida. A repercussão nas redes, assim, fez com que os memes se tornassem fonte de notícia.

\section{Diálogos fictícios entre Dilma e Angela Merkel}

O terceiro e último exemplo aqui trazido são os diálogos fictícios entre Dilma e Angela Merkel. Na final da Copa, a presidente Dilma Rousseff assistiu à cerimônia ao lado da chanceler alemã Angela Merkel. Cena retratando a conversa foi objeto de piadas criadas pelos internautas.
Aqui, novamente, os usuários se apropriam de uma cena exibida na televisão durante uma partida para fazer seus remixes. Porém, ao invés de modificar uma cena (caso 1) ou combinar uma cena com outras (caso 2), neste caso a cena circula tal qual como foi captada, acrescida de legendas engraçadas criadas pelos usuários, representando diálogos fictícios entre as líderes estatais envolvidas. Um exemplo dessa forma de apropriação pode ser visto na Figura 4.

Figura 4. Tweet fazendo piada com cena exibida durante o encerramento da Copa.

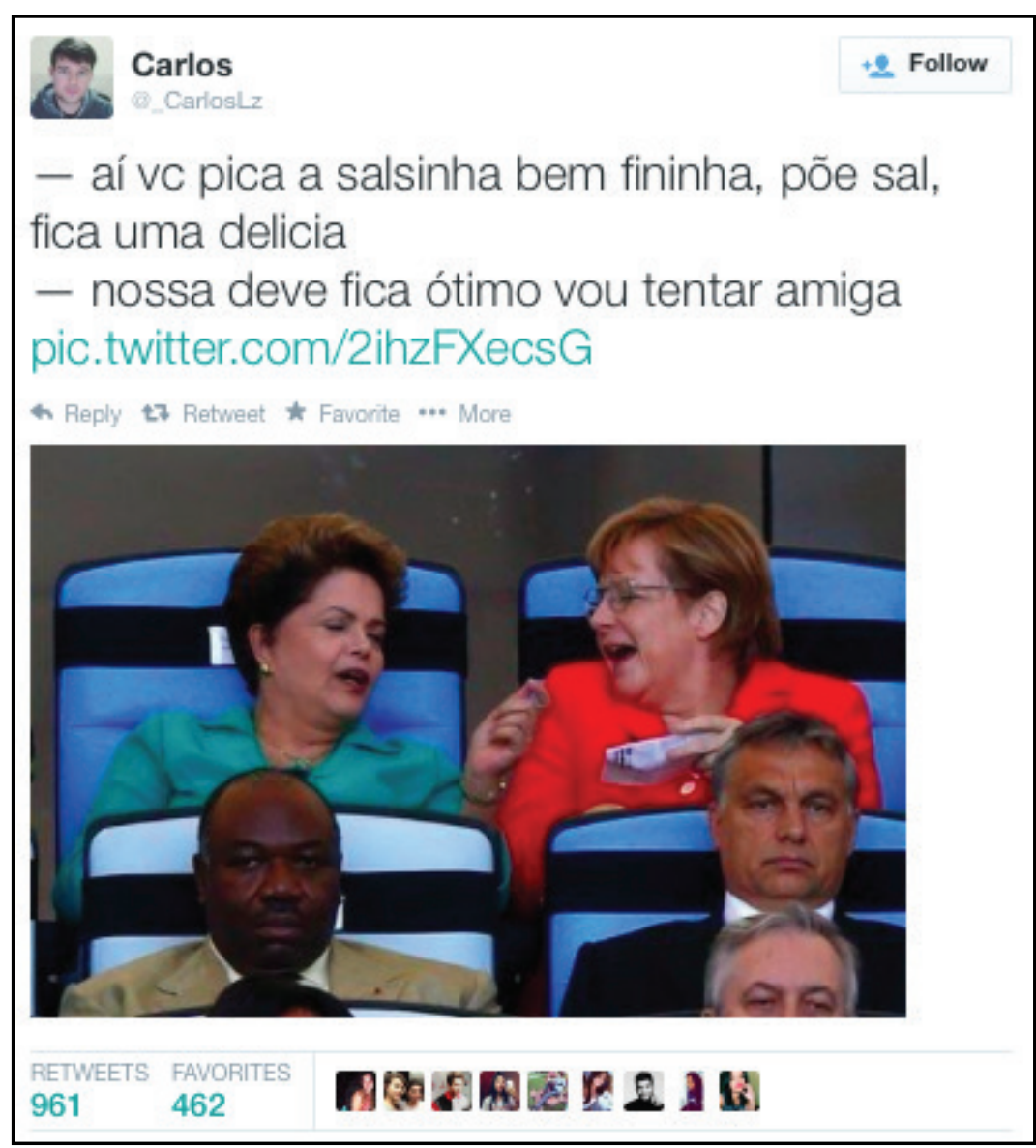

Fonte: http://vejasp.abril.com.br/blogs/ pop/2014/07/13/conversa-entre-dilma-e-angela-merkel-na-final-da-copa-do-mundo-vira-meme-

Essa prática decorre da possibilidade de incluir imagens nas postagens no Twitter, dentro do limite dos 140 caracteres, que são exibidas diretamente na timeline dos usuários.

Uma das legendas criadas para esse

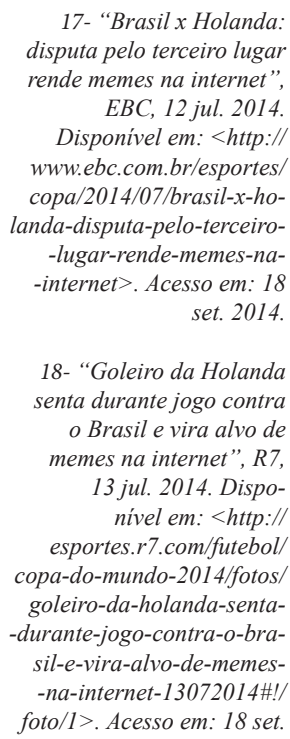

17- "Brasil x Holanda disputa pelo terceiro lugar rende memes na internet", EBC, 12 jul. 2014 Disponivel em: <http:// www.ebc.com.br/esportes copa/2014/07/brasil-x-holanda-disputa-pelo-terceiro-lugar-rende-memes-na-internet>. Acesso em: 18 set. 2014.

18- "Goleiro da Holanda senta durante jogo contra o Brasil e vira alvo de memes na internet", $R 7$ 13 jul. 2014. Disponivel em: <http://

esportes.r7.com/futebol copa-do-mundo-2014/fotos goleiro-da-holanda-senta-durante-jogo-contra-o-brasil-e-vira-alvo-de-memes-na-internet-13072014\#!! foto/1>. Acesso em: 18 set. 2014.
- aí vc pica a salsinha bem fininha, põe sal,

\section{- pic.tuitter.com/2 hzFXocs}

4 Reply tz Retweet * Favorite ... More

$$
\text { -no-twitter/ }
$$

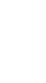


19- "Copa da Zoeira: os melhores memes da Copa do Mundo 2014 (FOTOS)", Brasil Post, 13 jul. 2014.

Disponivel em: <http:// www.brasilpost.com

br/2014/07/13/copa-do-mundo-2014-memes n 5582605 . html>. Acesso em: 18 set. 2014

20- "Conversa entre Dilma e Angela Merkel na final da Copa do Mundo vira meme

no Twitter", Pop! Pop!

Pop!, 13 jul. 2014. Disponi-

vel em: < http://vejasp.abril.

com.br/

blogs/pop/2014/07/13/

conversa-entre-dilma-e-

-angela-merkel-na-final-da-copa-do-

mundo-vira-meme-no-

-twitter/>. Acesso em: 18

set. 2014. meme aparece na compilação do Brasil Post ${ }^{19}$ dos melhores memes da "Copa da Zoeira”. O blog “Pop! Pop! Pop!” da Veja São Paulo ${ }^{20}$ aborda especificamente as piadas em torno da cena entre Dilma Rousseff e Angela Merkel.

Embora em formato ligeiramente diferente dos outros exemplos analisados, esse caso também decorre de um cenário de cibercultura remix. A facilidade no compartilhamento de imagens na rede fez com que o meme se propagasse ainda durante a partida da final da Copa o que, novamente, reflete a apropriação do Twitter como segunda tela e também como espaço de reverberação do humor. Esse caso também está associado à propriedade mutatória dos memes. A cada compartilhamento, novos sentidos eram atribuídos à imagem.

A partir dos casos destacados acima, é possível perceber que os sites de rede social se tornam um terreno fértil para 0 surgimento de pautas para os jornais, atuando como fonte para o jornalismo (Zago, 2011). O jornalismo em rede se situa nesse entrelaçamento entre jornais e sites de rede social, com as notícias se estendendo para além das fronteiras dos jornais.

\section{Considerações finais}

O trabalho procurou discutir o papel de piadas e remixes em torno da Copa do Mundo de 2014 diante de um cenário de jornalismo em rede. Após discorrer sobre jornalismo em rede, sites de rede social, e remix, três casos relacionados à Copa foram discutidos.

Os exemplos retratados representam três formas diferentes de apropriação de cenas da Copa do Mundo (modificação, justaposição e legendas criativas). A cria- ção e circulação desses memes decorre de um consumo televisivo associado a segunda tela. Além disso, essas práticas que se originam na rede podem, a partir de sua repercussão, acabar se tornando objeto de notícias. $\mathrm{O}$ jornalismo, assim, também se apropria de práticas do público, transformando em notícia a reverberação de um acontecimento.

A intensa circulação de piadas e remixes no Twitter durante a Copa, associada ao tratamento dado pelos veículos jornalísticos à cobertura do evento, ajudam a compreender o fato de ter sido apelidada de "Copa da zoeira".

Os casos estudados ilustram a relação das imagens de humor compartilhadas em sites de rede social com o jornalismo, enfatizando relações típicas de um jornalismo em rede. No jornalismo em rede, diferentes atores atuam como nós da rede do jornalismo, contribuindo de variadas formas para a produção e circulação de notícias e de narrativas sobre acontecimentos jornalísticos. Ainda que a piada, em si, não seja jornalismo, a repercussão da mesma passa a fazer parte do processo jornalístico ao se tornar pauta para os veículos.

Nessas situações, a grande circulação de um acontecimento com origem nas redes fez com que se tornasse objeto de notícia em veículos jornalísticos online, demonstrando a relação de complementaridade entre jornalismo e redes sociais. Nos casos ilustrados, os sites de rede social atuaram como fonte para o jornalismo, a partir da grande reverberação obtida pelas imagens compartilhadas e ressignificadas pelos usuários. 


\section{Referências bibliográficas}

BAR, F.; PISANI, F.; WEBER, M. Mobile technology appropriation in a distant mirror: baroque infiltration, creolization and cannibalism. Seminario sobre Desarrollo Económico, Desarrollo Social y Comunicaciones Móviles en América Latina. Anais... Buenos Aires: Fundación Telefónica, 2007.

BASTOS, M. Remix como polifonia e agenciamentos coletivos. In: MARTINS, C.; SILVA, D.; MOTTA, R. (Orgs.). Territórios Recombinantes: arte e teconologia, debates e laboratórios. São Paulo: Imprensa Oficial do estado de São Paulo, 2007. p. 27-34.

DAWKINS, R. O Gene Egoísta. São Paulo: Cia das Letras, 2007.

FINGER, C.; SOUZA, F. Uma nova forma de ver TV no sofá ou em qualquer lugar. Revista Famecos, v.19, n.2, 2012.

HAACKE, V.; HONORATO, J.; SOUZA, T.; GOVEIA, F.; CARREIRA, L. Do "Não Vai Ter Copa" para a "Copa dos Memes": uma análise das imagens memes mais compartilhadas durante a Copa do Mundo Figa 2014. XXXVII Congresso Brasileiro de Ciências da Comunicação. Anais... Foz do Iguaçu: Intercom, 2014.

HEINRICH, A. Network Journalism. Londres: Routledge, 2011.

HONG, S. Online news on Twitter: Newspapers' social media adoption and their online readership. Information Economics and Policy, v. 24, n. 1, p. 60-74, 2012.

LEMOS, A. Ciber-Cultura-Remix. Seminário Sentidos e Processos. Anais...2005

RECUERO, R. Redes sociais na Internet, difusão de informação e jornalismo: elementos para discussão. In: SOSTER, D.; SILVA, F. F. (Orgs.). Metamorfoses jornalísticas 2: a reconfiguração da forma. Santa Cruz do Sul: EDUNISC, 2009, p. 37-55.

RUSSELL, A. Networked: a contemporary history of news in transition. Cambridge: Polity Press, 2011.

SALAVERRÍA, R.; NEGREDO, S. Periodismo integrado. Barcelona: Sol90, 2008.

SOARES, T. O Videoclipe Remix. XVIII Congresso Brasileiro de Ciências da Comunicação. Anais... Rio de Janeiro: Intercom, 2005

ZAGO, G. O Twitter como fonte para o jornalismo. Animus, v.10, n.20, 2011.

Estudos em Jornalismo e Mídia está sob a Licença Creative Commons 2.5 